\title{
The Adoption of Proportional Representation
}

\author{
Lucas Leemann Columbia University \\ Isabela Mares Columbia University
}

\begin{abstract}
The debate between economic and political explanations of the adoption of proportional representation (PR) has yielded mixed results. We reexamine this debate and argue that one has to take the different levels on which the causal mechanisms are located into account. This leads to a novel reformulation of Rokkan's hypotheses: we claim that $P R$ is introduced when legislators face strong district-level competition and when their parties expect to gain seats from a change of the electoral law. In the empirical part, we model legislators' support for the PR adoption and evaluate the relative importance of district-level competition and vulnerability resulting from electoral inroads made by Social Democratic candidates; partisan calculations arising from disproportionalities in the allocation of votes to seats; and economic conditions at the district-level, specifically variation in skill profiles. Support for the adoption of $P R$ is explained by a combination of district vulnerabilities and seat-vote disproportionality.
\end{abstract}

T he study of the process of reform of electoral institutions during the first decades of the twentieth century and the adoption of proportional representation (PR) by some countries has been at the center of comparative research in recent years (Ahmed 2012; Benoit 2004; Blais, Dobrzynska and Indridason 2005; Boix 1999; Calvo 2009; Colomer 2005; Cusack, Iversen and Soskice 2007, 2010; Kreuzer 2010). ${ }^{1}$ This renewed interest in the origin of these political choices has been partly motivated by a related literature examining the importance of proportional representation in affecting a range of political outcomes, including the level of government expenditures, the types of social-spending programs, levels of inequality, and so on. While these studies have advanced a wide range of competing hypotheses about the economic and political determinants of these electoral reforms, the empirical tests formulated to adjudicate among these competing explanations remain inadequate. This empirical deficit arises because the core theoretical concepts of the literature have been either measured at a level of aggregation that is, we believe, uninformative or not measured at all.

Like any change in electoral rules, the adoption of proportional representation poses an immediate puzzle: why do politicians engage in risk-taking behavior and decide to replace the institutional rules on the basis of which they have been elected? Existing explanations for the reform of electoral institutions and the adoption of proportional representation cluster in two broad explanatory families, stressing either economic transformations or changes in the broader political environment as the source of political anxiety among right-wing politicians. Let us consider the larger political changes first.

Both hypotheses-stressing either the rise of Social Democracy or disproportionality in the allocation of votes to seats-as determinants for demand for changes in electoral institutions can be traced back to the work of Braunias and Rokkan (Braunias 1932; see also Rokkan 1970, 157-58). Contemporary studies seeking to explain the adoption of proportional representation have tested one of the two Rokkanian hypotheses. Boix (1999) has provided a cross-national test of the first Rokkanian hypothesis. In recent years, Calvo (2009) has revived this second Rokkanian explanation and has provided simulations informed by comparative cases to illustrate this logic.

In Rokkan's original study, the two political hypotheses acted as substitutes. Rokkan conjectured

\footnotetext{
${ }^{1}$ Support for this research was provided by the Center for the Study of Democratic Politics at Princeton University (2011). An online appendix with supplementary material for this article is available at http://dx.doi.org/10.1017/S0022381613001394. Data and supporting materials necessary to reproduce the numerical results will be made available at http://isabelamares.org and http://www.columbia.edu/ $\sim$ ltl2108/ upon completion of the research project.
}

The Journal of Politics, Vol. 76, No. 2, April 2014, Pp. 461-478

doi:10.1017/S0022381613001394

(C) Southern Political Science Association, 2014

ISSN 0022-3816 
that in some countries-such as Germany, Norway, or Sweden - the socialist mobilization played a significant role in accounting for the adoption of proportional representation, while in other countries-such as Belgium, Denmark, or Switzerland-considerations about the disproportionality of the translation of seats to votes were the primary factor in accounting for the motivation of politicians to adopt changes in electoral institutions (Rokkan, 1970, 157). In this article we argue, however, that the two political hypotheses are complements, rather than substitutes. Both explanations can operate within the same case, but capture constraints on the activity of legislators that operate at different levels. The first political explanation locates the salient constraint at the level of the electoral district, in district-specific electoral vulnerabilities encountered by candidates on the political right that face Social Democratic challengers. By contrast, the second Rokkanian explanation locates the salient constraint at the level of the party. An important task for the analysis is to identify the relative importance of district-specific vulnerabilities and partisan variables in affecting the preferences of legislators for changes in the design of electoral institutions.

The alternative economic perspective has been articulated by Cusack, Iversen, and Soskice (2007). ${ }^{2}$ According to this approach, "the choice of electoral systems is endogenous to the structure of economic interests" (388). The key structural economic conditions that are hypothesized to generate differences in political preferences and variation in political outcomes (adoption versus nonadoption of proportional representation) are the presence of "co-specific assets," in other words, investments in human capital that are jointly made by employers and workers (Cusack, Iversen, and Soskice 2007). Cusack and his colleagues hypothesize that in economies characterized by "consensual labor relations" and high levels of "co-specific" assets, economic actors consider majoritarian electoral rules as potentially detrimental to their long-term economic interests. First-past-the-post electoral systems allow groups with a narrow geographic base to capture political power and enact legislation that could potentially harm actors that had made long-term economic investments. In the presence of significant investments in skills, Cusack, Iversen, and Soskice predict that the most significant interest groups and the political parties to which they are tied will demand

\footnotetext{
${ }^{2}$ See Rogowski (1987) for an economically motivated alternative explanation, of PR adoption. In this explanation it is not the skill level but the degree to which a country is involved in international trade.
}

the adoption of proportional representation. By contrast, majoritarian institutions persist in economies with lower levels of co-specific assets. In contrast to the first family of explanations, economic hypotheses about the adoption of proportional representation derive their political predictions about the demand for changes in electoral institutions from the distribution of economic endowments and less from partisan or electoral considerations.

All explanations, political or economic in nature, are framed at a theoretical level that is quite abstract. Ultimately, they seek to explain choices made by individual legislators. As a consequence, many of these persistent disagreements cannot be resolved with the existing cross-national data. Additional leverage can be gained, however, by shifting to a lower level of empirical aggregation, the individual politician. This move to the individual level is desirable for a number of reasons.

First, the dominant empirical strategy pursued in contemporary research which is premised on quantitative analysis of variation among a small number of countries is severely constrained by the small number of observations. The number of observations in crossnational studies is relatively low, varying from 24 in the original Boix article of 1999 to 12 in some of the specifications presented in Cusack, Iversen, and Soskice (2007). This small number of cases, coupled with a high multicollinearity among competing variables has limited our ability to assess the relative importance of competing explanations. This constraint might also explain why so far scholars have been unable to test all three explanations of the adoption of proportional representation but have tested only one or two theories at a time. Second, an analysis that is situated at the individual level is also preferable because some of the central predictions of the first political hypothesisstressing the importance of electoral vulnerabilitiesare located at the level of the electoral district. Existing studies that have relied on cross-national data have measured many of the relevant variables capturing political competition at a level of analysis that is too aggregated and, thus, uninformative Cox (1997). Rather than assuming that parties are the decisive level, we start at the lowest level and use hierarchical models which allow for parties being the decisive actor while not presupposing it.

The difficulty and real challenge for an empirical evaluation of competing explanations of PR adoption using roll-call data is the development of measures of the core explanatory variables of the economic explanation, the level of "co-specific assets." We take up this challenge in this article and develop precise 
estimates of the ratio of skilled workers at the level of the electoral district. This allows us to bring competing explanations about the adoption of proportional representation to a common empirical unit of analysis and assess, for the first time, the relative effect of structural economic conditions at the level of the district, electoral competition and partisanship on individual level support for the adoption of proportional representation.

Our article examines a decisive vote taken by the German Reichstag as a result of which Germany adopted proportional representation. ${ }^{3}$ The German case occupies a central position in all explanations that have been advanced to explain the adoption of proportional representation. Consider first its importance for political explanations of changes in electoral institutions. The existing literature treats Germany as the paradigmatic case that illustrates the importance of the Social Democratic threat as the catalyzing factor leading to a change in the position of right-wing parties over the desirability of proportional representation. This interpretation of the German case goes back to the classic studies of the adoption of proportional representation, such as Braunias (1932) or Rokkan (1970). As Rokkan argued, in countries where hostility and distrust among existing parties on the right was too strong, the latter found it impossible to make common cause against the socialist threat. As such, they preferred proportional representation, a system that guaranteed them the ability to compete independently $(1970,158)$. This account, however, has difficulties in explaining the diverging positions taken by different parties on the political right over the question of electoral-reform change. While the Catholic Zentrum and the German Conservative Party opposed the adoption of proportional representation, both the National Liberals and the Free Liberals supported the adoption of changes in electoral institutions. Thus, it appears that both political explanations seem to capture important determinants of the motivations of politicians to support changes in electoral institutions, but so far no study has attempted to disentangle the relative explanatory power of these two explanations. Germany is a great case to test hypotheses about the effect of Social Democratic mobilization on the adoption of proportional representation. Germany expanded the suffrage early (1871); the left did not burst on the political scene so dramatically as in other countries that adopted the franchise much later. Moreover, the early franchise expansion generated lower political uncertainty about

${ }^{3}$ This represents the only recorded vote on the issue of proportional representation taken by the German Reichstag during the period between 1870 and 1918 (see also Hatschek 1920). electoral outcomes, as compared to the countries in which franchise expansion was much closer to PR adoption (Ahmed, 2010; Andrews and Jackman 2005). ${ }^{4}$

Germany is also the case that motivates the economic explanation of the adoption of proportional representation. The extensive network of vocational training (Thelen 2004) that was well-established during the Nineteenth century led to the development of a workforce characterized by high ratios of skilled workers and an unusually high level of vocational skills (Kaiserliches Statistisches Amt 1899, 73; Bade 1980). The central hypothesis advanced by Cusack, Iversen, and Soskice (2007) suggests that the regional variation in the distribution of human capital has important political consequences both for the adoption of proportional representation and for democratization more broadly. Germany takes high values on the measures of economic coordination developed by Cusack and his colleagues (2007). Our own measure of skills - which tests the theoretical mechanism that underpins this argument directly-shows that Germany exhibited very high levels of skills in many industrial occupations. Germany occupies, thus, an asymmetric position for economic and political explanations and represents a "hard" case for Rokkanian explanations (George and Bennett 2005). Due to this asymmetry, empirical results that disconfirm importance of human capital as a predictor of the adoption of proportional representation in the German case can weaken our confidence in the comparative explanatory power of the economic approach to the origin of proportional representation.

The following section explores the tensions among the two political hypotheses concerning the determinants of support of changes in electoral institutions and formulates both the hypotheses and the empirical strategy used to assess the relative importance of partisan considerations and district-level electoral competition on legislator support for changes in electoral institutions. We turn next to the economic explanation, discuss its empirical predictions, and then discuss our measures of human capital distributions across electoral districts.

\section{Economic Conditions, Political Competition, and the Change of Electoral Institutions}

Stein Rokkan's shadow looms over much of the contemporary research seeking to explain the adoption

\footnotetext{
${ }^{4} \mathrm{We}$ are grateful to an anonymous reviewer for stressing this aspect.
} 
of proportional representation in Europe during the first decades of the twentieth century (Rokkan 1970). Two of the dominant hypotheses concerning the adoption of proportional representation can be traced back to his work. The first of these argues that incumbent elites support the adoption of proportional representation to avoid a complete electoral disaster in the face of Social Democratic mobilization (Rokkan 1970). Boix takes up this hypothesis and argues that if parties on the political right are equally balanced in their electoral strength, but unable to coordinate on a common candidate (either at the level of the constituency or nationally), then they are likely to support the adoption of proportional representation. By contrast, the incentives to adopt changes in electoral institutions are weaker if one party dominates the electoral arena Boix (1999, 612).

Rokkan's second hypothesis-taken up in current research by Ernesto Calvo (2009)—attempts to specify conditions under which incumbent parties on the right favored changes in electoral institutions even in the absence of Social Democratic threats. This hypothesis suggests that parties with a geographical dispersed distribution of votes also faced incentives to demand changes in electoral institutions, as multiparty competition increased the seat-vote disproportionality of the electoral results. According to this logic, the adoption of proportional representation is regarded as a mechanism to reduce the "severity of the partisan bias and of electoral regimes to districting problems" (Calvo 2009, 256)..$^{5}$

The two Rokkanian hypotheses differ in the relative importance placed on the Social Democratic threat. Both hypotheses stress, however, "electoral coordination" (or failure thereof) of incumbent parties as a critical variable influencing the decision of incumbents to support or oppose changes in electoral rules and the adoption of proportional representation. Critics have noted that the notion of electoral coordination is theoretically unclear and poorly operationalized empirically. Cusack et al. note two limitations of the test of electoral coordination presented in Boix (Cusack, Iversen, and Soskice 2007, 375). The first is the failure to take account of the opportunities for coordination created in electoral systems that used runoffs. Runoffs allowed parties on the political right that competed in the first round to form electoral alliances in the second round to oppose a Social Democratic candidate.

\footnotetext{
${ }^{5}$ This hypothesis is sometimes alternatively labeled "minority representation thesis" (Caramani 2004) or "electoral geography thesis" (e.g., Norris 1997).
}

Cusack and his colleagues note some limitations of the empirical test of the Rokkanian notion of electoral coordination employed by Boix and argue that the variable used by Boix, the "effective number of parties" fails to distinguish between cases in which one party on the right is dominant from cases where parties of the right are equally sized $(2007,375)$. A similar critique is presented by Blais, Dobrzynska, and Indridason (2005) who argue that the incentives of all parties to switch to proportional representation are stronger in countries which require a majority rather then just plurality of the votes to take a district.

While raising these criticisms, Cusack, Iversen, and Soskice (2007) do not propose a superior empirical solution. It is impossible to measure district-level electoral competition with cross-national data. Using aggregate data we cannot learn whether or not there was coordination on the right. Clearly, runoffs could alleviate potential coordination problems among parties on the right. However, while runoffs induce some electoral coordination during the second round, they do not necessarily produce electoral coordination among right-wing parties (Bertram 1964; Fairnbairn 1990; Reibel 2007). Parties on the political right have a range of possible strategies during runoffs. These include the formation of preelectoral coalitions which are restricted to right-wing parties, political support for the left-wing candidate over the right-wing opponent (in districts where a candidate on the right encounters a candidate on the left during runoffs) or recommendation to their voters to abstain during the second round (and their de facto refusal to endorse any of the remaining candidates). We provide a number of examples in the online appendix to illustrate how abstention recommendations contributed to the Social Democratic victories.

Studies emphasizing the economic foundations of proportional representation do not derive the demand for the adoption of proportional representation from partisan expectations about their electoral survival, but from the expectations of leading economic groups (employers and labor) about the different regulations that might emerge under different electoral rules. Thus, what distinguishes the trajectory of PR from non-PR adopters is the level and depth of investment in skills made during the early stages of industrialization. As Cusack, Iversen, and Soskice formulate, their hypothesis linking specific assets and proportional representation:

Two broad alternative patterns of labor and skill regulation in industry can be found at this critical period in the early twentieth century. They relate to the question of the control of skilled formation and the 
content of skilled jobs. The first possible alternative, which we find subsequently in each of the PR adopters, was some form of cooperative agreement between business and unions: in exchange for collective bargaining rights and monitoring of skill formation, business would have managerial control of the shop floor and determine training levels. This alternative had major implications for the politics of regulation because skills in this system are co-specific assets.... Unions and employers become vulnerable to opportunism and holdup and they consequently need credible long-run guarantees which include an appropriate framework agreement at the political level to underwrite the relevant labor market and social security institutions and rules. The political system has to be such that the agreement cannot be changed by a change of government without the consent of other groups. This requires not just a system of proportional representations to enable the different groups to be represented through parties, but also a political system that allows for consensus decision making in the regulatory areas that concern them. $(2007,328)$

We interpret the argument as generating two testable empirical implications. The first is that in countries or regions where investments in specific skills are higher, economic actors seek to establish proportional systems of representation either independently or through their partisan representatives. By contrast, the demand for proportional levels of representation is lower in regions with lower levels of co-specific assets. Secondly, regions characterized by high levels of investment in skills also experience more consensual relations in the industrial sphere and among parties.

Yet, despite the straightforward nature of this empirical implication, Cusack, Iversen, and Soskice have not yet provided a direct empirical test of their theory. In their cross-national analysis, the variable used to test the importance of "co-specific assets" is a composite variable that includes the strength of employer associations and the existence of rural cooperatives and preexisting guilds. The other indicator, the strength of employer associations, is a problematic empirical measure. As Kuo (2010) has illustrated, most employer associations that existed in Europe prior to World War I (and thus prior to the adoption of proportional representation) were established with the explicit goal to repress labor movements. The existence of a coordinated employer association does not proxy for harmonious labor relations and co-specific investments, the critical variable of this theory.

The most recent American Political Science Review article which restates the asset-specific explanation and offers limited qualitative evidence discussing electoral reforms in Imperial Germany does not provide any direct measures of human-capital development across German regions. Saxony, Württemberg, and Baden are used interchangeably as being, presumably, cases that share similarly high endowments of human capital (which is the hypothesized factor leading to the adoption of proportional representation). Cusack, Iversen, and Soskice (2007) provide no empirical evidence to support these conjectures. At the turn of the century, Baden and Württemberg are relatively underdeveloped regions of the German Empire, displaying levels of agricultural employment that are higher than the respective levels in the Reich (Hohls and Kaelble 1989, 167-87). ${ }^{6}$ Our estimates of humancapital development - which computes ratios of skilled workers to total workforce-present roughly similar patterns. The national average is $36.2 \%(\mathrm{sd}=9.0)$ and while Saxony reaches $52.7 \%(\mathrm{sd}=3.01)$, we find that Baden has $36.8 \%$ ( $\mathrm{sd}=2.8$ ), and Württemberg is slightly below average with $35.8 \%(\mathrm{sd}=1.47)$. These measures do not support the argument that all three regions (Saxony, Baden, and Württemberg) share high endowments in human capital (see also Fremdling and Tilly 1979). Thus, qualitative assessment of nineteenth-century economic realities (which are likely to be based on twentiethcentury outcomes) turn out to be inaccurate. Given that the core explanatory variable (distribution of "asset specific investments") takes different values across these regions, it cannot serve as the common explanation for subnational electoral reforms.

While the debate between economic and political explanations of the adoption of proportional representation has occupied a visible place in prominent publications, it has not yet been resolved. Quite the contrary. This inconclusiveness has several reasons. Existing explanations have been brought to the data only imperfectly. Ambiguity exists as to what constitutes electoral coordination and how it should be operationalized. Many of the existing tests of the first Rokkanian hypotheses have only assessed the effects

\footnotetext{
${ }^{6}$ At the time of the 1895 census, the share of the labor force employed in agriculture in Baden and Württemberg stood at 44 and $45 \%$, respectively. The average agricultural share for the entire Reich stood at 37\%. By contrast, Saxony's share of agricultural employment stood at $17 \%$. These relative levels of economic development did not change much until 1905-1907, the period when the last economic census prior to World War I was assessed. The employment shares in agriculture in Baden declined from 45 to $40 \%$ but remained relatively stable in Württemberg at $45 \%$. In both regions, levels of industrial development continued to be below that of the Empire (which stood at 35\% in 1905). By contrast, Saxony's share of agricultural employment stood at $13 \%$ in 1905 . The figures are based on the aggregate results of both economic censuses presented in Hohls and Kaelble (1989, 167-208).
} 
of variation in national-level competitiveness on the probability of transition to proportional representation. This remains both an imperfect test of the first Rokkanian hypothesis which has to be tested using more disaggregated subnational and district-level measures. The empirical assessment of economic explanations is a necessary step in the evaluation of competing explanations for the adoption of proportional representation. For this endeavor, the lack of a measure of the core explanatory variable, the co-specific assets, is an outstanding difficulty.

\section{A Theoretical Reformulation of the Rokkanian Hypotheses}

The two political hypotheses locate the prime determinant of legislators' calculations about the attractiveness of different electoral rules at different levels of analysis, the individual district versus the party. The first hypothesis highlights electoral vulnerabilities at the level of the district. In this hypothesis, the general contestation of a race, the availability or absence of coalition partners, the strength of the contender on the left, and the potentially scarring experience of a runoff are likely to affect the decision of a politician to support changes in electoral institutions. By contrast, the second political hypothesis locates the important determinant at the level of the party and not the district. Partisan preferences over the desirability of different electoral rules are influenced by the attractiveness (or its absence) of the way in which the policy status quo allocates votes to seats. In their calculation about the relative attractiveness of different electoral rules, politicians are constrained both by district-specific factors and by the general considerations of their party. The partisan and district-level incentives can reinforce each other for support of particular electoral rules, but they can also come into tension. Consider the case of a politician representing a party from the right that experiences an unfavorable distribution of votes to seats and who has been elected by a narrow margin in a runoff against a Social Democratic opponent. For this particular politician, the constituency-level incentives and the partisan incentives reinforce each other, and one expects this politician to support the adoption of proportional representation. Partisan and district-specific electoral incentives may, however, come into tension.

By hypothesizing that the two political explanations about the origin of proportional representation highlight political incentives that are located at different levels of analysis, we challenge a number of statements made by Rokkan. Instead of viewing the two political hypotheses as separate roads to proportional representation undertaken by different countries, we argue that both logics can be at work within the same country. The two hypotheses specify different constraints on the behavior of legislators. To formulate this point more starkly, there are no two roads to proportional representations, but two distinct sets of political constraints on the behavior of politicians, which operate at the level of the district and party, respectively. A legislator-based account of the origin of proportional representation allows us to disentangle the relative effects of these constraints.

\section{District-Level Vulnerabilities versus Partisan Constraints}

To test the implications of the first Rokkanian hypothesis, we examine the consequences of district-specific factors on the probability of support of changes in electoral institutions. We hypothesize that three variables linked to the contestability of a race are likely to affect the support of the legislator for changes in electoral institutions. The first is whether the politician is elected in the first round or a runoff. All things equal, we hypothesize that politicians elected in runoffs are more vulnerable than politicians elected during the first round. Runoffs are themselves an indicator of coordination difficulties for parties on the right. As such, we hypothesize that politicians on the right elected during runoffs are more likely to support changes in electoral institutions than politicians elected during the first round. A second district-specific factor that is likely to affect preferences towards electoral institutions is the margin of victory. All things equal, politicians elected in races with larger margins are more likely to support the policy status quo than politicians elected in more contested races with narrower margins. A final prediction of the first Rokkanian hypothesis is that the magnitude of the threat of the Social Democratic Party (as measured by the vote share of the Social Democratic candidate during the first round) is likely to increase support for changes in electoral institutions.

We include three variables to test for these hypotheses linking electoral vulnerability in the district and preferences for changes in electoral institutions. They include a variable that takes the value of 1 when the politician was elected during runoffs, a measure of the margin of victory during the decisive electoral round and a measure of the vote share of the Social Democratic candidate. In combination, these variables allow us to capture only the theoretical expectations laid 
TABLe 1 Seat-Vote Disproportionality for the Largest Parties in the Reichstag during the 1912 Election

\begin{tabular}{lcccc}
\hline Party & $\begin{array}{c}\text { Vote } \\
\text { Share }\end{array}$ & $\begin{array}{c}\text { Seat } \\
\text { Share }\end{array}$ & Disproportionality & $\begin{array}{c}\text { Prediction of } \\
\text { Rokkan II }\end{array}$ \\
\hline Social Democrats & $34.8 \%$ & $27.7 \%$ & -7.1 & $\begin{array}{l}\text { Support of PR } \\
\text { Zentrum }\end{array}$ \\
National Liberals & $16.8 \%$ & $22.9 \%$ & 6.1 & Opposition to PR \\
Conservatives & $13.6 \%$ & $11.3 \%$ & -2.3 & Support of PR \\
Free Liberals & $11.6 \%$ & $14.1 \%$ & 2.5 & Opposition to PR \\
Minorities & $13.1 \%$ & $10.6 \%$ & -2.5 & Support of PR \\
& $4.5 \%$ & $8.3 \%$ & 3.8 & Opposition to PR \\
\hline
\end{tabular}

Source: Reibel (2007) based on Kaiserliches Statistisches Amt (1913, 4-103) and www.wahlen-in-deutschland.de.

out by the first Rokkanian hypothesis. They capture district-specific electoral constraints. They remain insufficient in capturing the full set of political constraints and considerations facing the politician. To understand the latter, we need to consider partisan considerations about the effects of the electoral formula on the electoral fate of the party. We turn to a discussion of these considerations next.

\section{Partisan Preferences about Changes of Electoral Rules}

The second political hypothesis formulates its predictions at the level of the party rather than district. In this hypothesis, the key variable that is likely to affect the preferences of parties about the adoption of proportional representation is the disproportionality in the allocation of seats to votes under the existing electoral rules. Parties that benefit from the current allocation of seats to votes (by obtaining a higher seat than vote share) are likely to favor the policy status quo. By contrast, parties that lose from the allocation of seats to votes are likely to favor changes in electoral institutions and the adoption of proportional representation.

Table 1 presents descriptive information on the effects of disproportionality for the major political parties during the 1912 election of the Reichstag, which elected the deputies that ultimately adopted the legislation introducing proportional representation. We group existing deputies in six partisan families, which include Social Democrats (who at the time obtained the largest number of votes), the Zentrum, National Liberals, Free Liberals, Conservatives, and parties representing minorities (such as Poles or the Elsass independents). Column 2 presents information on the number of votes cast for these candidates, column 3 on the number of seats held by the respective party during the last session of the Reichstag. Column 4 presents the measure of seat-vote disproportionality for the party and column 5 the prediction about support for changes in electoral institutions.

As Table 1 illustrates, the Social Democratic Party experienced the most disfavorable ratio in the allocation of votes to seats. Industrialization which led to the concentration of voters in urban areas aggravated the disproportionality experienced by the Social Democratic Party (Boix 2010). The disproportionality worsened from $(-2.6)$ in 1871 to $(-7.1)$ percent in 1912. As a result, the Social Democratic Party became the staunchest advocates for the introduction of proportional representation. During the period leading to World War I, Social Democratic candidates cosponsored legislation recommending the introduction of proportional representation in national elections for the Reichstag and actively advanced similar proposals during discussions of electoral reforms of the subnational parliaments (Schmädeke 1995). Several studies assume that Social Democratic parties were supportive of the adoption of proportional representation. As recent studies have pointed out, this assumption may be inaccurate and cannot adequately account for the observed empirical variation in the preferences of Social Democratic parties across Europe on the question of electoral reform (Ahmed 2012; Penadés 2008). We can, however, derive theoretically the preferences of Social Democrats by taking seat-vote disproportionality into account.

Among the parties on the right, the two prominent losers in the allocation of votes to seats were the Free Liberals and National Liberals. The disproportionality index during the 1912 elections stood at $(-2.5)$ for Free Liberals and at $(-2.3)$ for National Liberals. In contrast to Social Democrats that had been disfavored by the allocation of votes to seats during all elections of the period, for the two parties on the right the disproportionality in the allocation of votes to seats was a more recent phenomenon that came 
into place during the last elections of the Reichstag (Duverger 1963, 375). Party leaders from these two parties embraced the idea of proportional representation later than the Social Democrats, and the question about the advantage of this electoral reform remained the subject of significant intra-party disagreement Gagel (1958, 125-41). For Free Liberals, the push for the adoption of proportional representation originated with party leaders from Southern German states where the presence of Catholic minorities in some districts could lead to the waste of votes won by the Free Liberal candidates under the existing single-member electoral system (Simon 1969).

The two large political parties on the right that benefited from the allocation of seats to votes were the Zentrum and the Conservatives. Party leaders from both parties understood the electoral advantage of existing electoral institutions and rejected the introduction of proposals calling for the adoption of proportional representation (on Zentrum: Penadés 2011; on Conservatives: Kühne 1994). This opposition to any reform of the electoral system remained one of the issues that brought these two partieswhich had been bitter enemies during the Kulturkampf-together and led to the creation of the "black-blue" electoral alliance during the 1912 election (Bertram 1964; Reibel 2007).

An internal report commissioned by the German Interior Ministry (Reichsamt des Innern) in the immediate aftermath of the 1912 election noted the divergent rates of success of different parties of the right in translating their votes into seats. The report observed that while the "Liberal Party obtained over 3 million votes in 1912, it was able to obtain only 4 seats in the first round, while the Zentrum obtained over 80 seats with only 2 million votes. "The explanation for this fact is", the report noted, "that there are no areas where there are only Liberals; rather there are areas where there are Liberals and either Conservatives, or Zentrum or Social Democrats" (Bundesarchiv Berlin Lichterfeld R1501/192-193). Prominent liberal politicians also noted the worsening seat-vote disproportionality encountered by their party and began to advocate the adoption of proportional representation (Brandenburg 1917, 30; Gagel 1958, 128).

Social Democrats had militated for changes in electoral institutions beginning with the 1891 Erfurt congress. By contrast, Free Liberal and National Liberal politicians began to advocate the adoption of proportional representation only much later (Gagel 1958). This shift in the position on the desirability of electoral reform advocated by these two parties on the right guaranteed the formation of an encompassing political coalition supporting the adoption of proportional representation. The political factor that motivated this change in strategy among these two parties on the right was the worsening of their seat-vote disproportionalities.

Let us consider how considerations about the translation of votes to seats affected the policy positions of a range of parties on the question of electoral reform. From the perspective of the Social Democratic Party, calculations of their expected vote share under this alternative electoral rule (that used as input the number of votes received during the 1907 election) revealed an expected gain of 76 seats (from 43 to 117 seats; Andersen 2000, 343; Fricke 1961). Both National Liberal and Free Liberal Parties that experienced losses in the translation of votes to seats under the existing electoral rules also favored the adoption of proportional representation (Andersen 2000, 343; Gagel 1958, 143). By contrast, the two other parties on the right that gained from the allocation of the votes to seats under single member electoral rules-the conservatives and the Zentrum-opposed changes in electoral rules. A recommendation of the Ministry of Interior summarizes the fear of Conservatives about changes in electoral rules. The adoption of proportional representation, this study showed, would reduce the seat share of conservative parties by eight seats (as compared to the 1912 results) and "cannot be regarded as a cure against the existing inequalities in representation". The expected loss of seats for the Zentrum, as compared to its 1912 electoral results, stood at 32 seats (Bundesarchiv Berlin Lichterfeld R1501/343).

We have begun to explore the implication of the second Rokkanian logic for the preferences on reform of electoral institutions. Parties losing from the allocation of votes to seats (Social Democrats, National Liberals, and Free Liberals) supported the introduction of proportional representation. By contrast, winners of vote seat disproportionality (Conservatives and Zentrum) opposed it. How constraining were these desiderata of party leaders on the decisions made by individual legislators during the actual vote of electoral reforms? Our empirical analysis allows us to explore these questions and examine whether individual legislators internalized these needs of their respective parties and of the relative effect of district specific vulnerabilities in affecting their calculations. To test how the disproportionality in the allocation of votes to seats affects the preferences of party leaders, we include the measure of disproportionality (SEAT VOTE DISPR.) as additional control in our analysis of the vote choice of legislators. 


\section{Asset Specific Investments and the Adoption of Proportional Representation}

Both Rokkanian explanations are political explanations. They locate the source of demand for changes in electoral institutions in either electoral vulnerabilities at the district or in partisan calculations. The causal chain presupposed by these hypotheses is relatively short: politicians, it is hypothesized, respond either to their increased electoral vulnerability or to calculations about the translation of votes into seats. By contrast, economic explanations locate the source of political demand for electoral change in economic conditions at the local level or the regional level. The causal chain linking these economic factors the actions of legislators is long and tenuous. In this alternative explanation, politicians favor the adoption of proportional representation not because it serves an immediate political need but because they expect that proportional representation will produce more favorable labor regulation that will protect the "asset specific investments" made by employers and firms in their districts (Cusack, Iversen, and Soskice 2007, 2010). Let us suspend possible questions about the farsightedness of politicians and assume that this logic captures plausible political constraint on the activity of legislators (e.g., Andrews and Jackman 2005). The empirical question that we seek to answer is whether structural conditions at the district level affect the political choices made by legislators once we control for all the other relevant political factors (Rokkan 1 and Rokkan 2) that presuppose a much shorter causal chain. As the argument rests on local economies that differ in their levels of co-specific investments and where politicians respond to the political demands of firms and workers that have made these specific investments in skills. As such, the district level —a level where individual politicians come into direct contact with these economic actors-is an essential level of analysis at which the argument can be tested. However, given that this theoretical contribution is vague about the specific level at which this mechanism applies, we also investigate empirically whether the mechanism operates at the level of the region or at the level of the party.

Above, we have noted that non-Rokkanian approaches have not yet tested the core element of their explanation-which hypothesizes that support for proportional representation can be predicted by high levels of "asset specific" investment. We seek to remedy these shortcomings and replace the imprecise characterizations of variation in "co-specific assets" with actual measures of human-capital development across German electoral districts, regions, and parties.
While difficult and computationally intensive, it is possible to compute measures of the distribution of human capital across German regions prior to the adoption of proportional representation.

We use two distinct sources of the German occupational census to compute this measure. First, we start with tables of the ratio between skilled and unskilled workers. As part of its 1895 census, the German Statistical Agency has collected information on the ratio between skilled and unskilled workers in 183 occupations, which includes 161 industrial occupations and 22 occupations in services. The definition of skilled workers ("gelernte Arbeiter") employed by the Statistical Agency is straightforward (but somewhat laconic): "skilled workers (gelernte Arbeiter) are those workers that require some training. By contrast, unskilled workers (ungelernte Arbeiter) -in other words manual workers, handymen, and other workers in services-which do not have "existing training” (Kaiserliches Statistisches Amt 1899, 73). The study noted that the number of skilled workers is very high in Germany (nearly $50 \%$ of workers employed in industry). "The economic relations in industry-which requires particular abilities and skills which can be learned or acquired through persistent exercise are the decisive factor which explain these high ratios of skills" (Kaiserliches Statistisches Amt 1893, 73). We present the disaggregated levels of skills for all 161 occupations in the online appendix (Table A8; further information is in Section A2 of the online appendix).

Our second input is Germany's occupational census. In addition to the information on skill profiles of occupation, the 1895 occupational census (Gewerbezählung) contains extremely disaggregated information on the employment shares across these 180 occupations in 1,003 German localities. ${ }^{7}$ These two sources allow us to estimate the ratio of skilled to unskilled industrial workers across each locality. In a final stage, we aggregate localities at the district level to obtain measures of the density of human capital across the 397 electoral districts of Imperial Germany. Using the number of skilled workers in each district as an input, we compute two measures of skill profiles that differ in their respective denominator. The first is a measure of skills as a percentage of

\footnotetext{
${ }^{7}$ The occupational census-which is the main source for the construction of our skill variable-presents the information at a very disaggregated level of analysis, the commune. To aggregate information from over 1000 communes to the level of the electoral districts, we rely on Reibel (2007), who presents detailed information of the boundaries of the 397 electoral districts.
} 
workers employed in industry (SKILL). The second is a ratio of skilled workers to all employed persons in the district (SKILL LEVEL). Finally, we also use a measure of skills aggregated at a higher level which corresponds to the 29 subnational political units (SKILL REGION). ${ }^{8}$ We present the results using the second and third measure of skills in the online appendix of the article (Table 1, Table 2, Table 3, and Table 4).

\section{Empirical Analysis: Explaining Support for the Adoption of PR}

The dependent variable in our analysis is the support for a bill recommending the adoption of proportional representation and "the creation of larger electoral districts" (Stenographische Berichte des Deutschen Reichstages 13). The bill was approved by a rather narrow political margin of $10 \%$ points, with $55 \%$ of deputies voting in favor, $45 \%$ deputies opposing it, and three casting invalid ballots. The vote in the Reichstag represents the endpoint of an intense (but relatively short) period of parliamentary negotiations of changes in electoral institutions for elections to the second chamber of the national parliament. We conducted an extensive search of all legislative bills recommending the introduction of proportional representation throughout the 13 legislative sessions of the Reichstag between 1870 and 1912, but we only found legislative initiatives recommending the adoption of proportional representation during the 13th Reichstag that was elected in 1912.

\section{Empirical Evidence for Motivations to Change Electoral Systems}

We attempt to solve the puzzle presented by the existing literature on the origin of proportional representation; competing explanations of this political choice differ widely in their postulated causal mechanisms. Our test is decisive in adjudicating among these competing explanations for a number of reasons.

First, it has the crucial advantage that it is carried out at the lowest possible level of analysis, the individual level, and subsequently we can aggregate and move further up. This allows us not to presuppose

\footnotetext{
${ }^{8}$ The online appendix presents yet another operationalization which is based on parties. We compute the average value of district skill levels over all districts a party holds (see the online appendix for more details).
}

a level but to actually test which level can contribute to the explanation. Since the decision to change an electoral system is made by a politician representing a district, we should be relying on district-specific measures; we can use the margin of victory in a district instead of relying on a country wide average to gauge the closeness of vote outcomes. Secondly, it allows us to test for a range of additional factors-most notably the partisan concerns about disproportionality-that have not yet been incorporated into a economic models explaining electoral system change. Finally, our measures of the theoretical concepts invoked by various explanations (such as asset specific investments) are, we believe, more precise than the existing indicators of coordination used in cross-national research. ${ }^{9}$ The latter measures are both quite distant from the core variables that are hypothesized to affect the outcomes ("skills") and also susceptible to measurement error (Kreuzer 2010).

We carry out a full test that includes the salient variables in each of the main hypotheses in the literature, including the second Rokkanian hypothesis. We use predictors originating from all three political explanations: district specific vulnerabilities and socialist threat (Rokkan I), seat-vote disproportionalities (Rokkan II), and levels of skills acquired through the vocational training system Cusack, Iversen, and Soskice (2010). This is not only the first test that includes all the variables but also the first time that these hypotheses are tested at the district level, the regional level, and the partisan level.

The models presented in Table 2 operationalize all three hypotheses. Our test of the second Rokkanian hypothesis is the degree of disproportionality in the translation of votes to seats. We use the dataset on electoral politics in Imperial Germany (1871 to 1912) which we cross-check with Reibel (2007) to determine the partisanship of the winning politician in each district.

The measure of disproportionality (SEAT VOTE DISPR.) takes higher values if the share of seats held

\footnotetext{
${ }^{9}$ The variable used by Cusack, Iversen, and Soskice (2007) to test the importance of "co-specific assets" is a composite variable that includes the strength of employer associations and the existence of rural cooperatives and preexisting guilds. The other indicator, the strength of employer associations, is a problematic empirical measure. As Kuo (2010) has illustrated, most employer associations that existed in Europe prior to World War I (and thus prior to the adoption of proportional representation) were established with the explicit goal to repress labor movements. The existence of a coordinated employer association does not proxy for harmonious labor relations and co-specific investments, the critical variable of this theory.
} 
TAble 2 Regular Probit and Hierarchical Probit Models on PR Vote

\begin{tabular}{|c|c|c|c|c|c|c|c|c|}
\hline & Model 1 & Model 2 & Model 3 & Model 4 & Model 5 & Model 6 & Model 7 & Model 8 \\
\hline \multicolumn{9}{|l|}{ Partisan } \\
\hline SEAT VOTE DISPR. & $\begin{array}{l}-0.301^{\star * *} \\
(0.037)\end{array}$ & $\begin{array}{l}-0.391^{\star * *} \\
(0.056)\end{array}$ & $\begin{array}{l}-0.406^{* * *} \\
(0.058)\end{array}$ & $\begin{array}{l}-0.414^{\star * *} \\
(0.061)\end{array}$ & $\begin{array}{l}-0.317^{\star * *} \\
(0.102)\end{array}$ & $\begin{array}{l}-0.362^{\star * *} \\
(0.112)\end{array}$ & $\begin{array}{l}-0.381^{\star * *} \\
(0.107)\end{array}$ & $\begin{array}{l}-0.393^{\star * *} \\
(0.106)\end{array}$ \\
\hline \multicolumn{9}{|l|}{ District } \\
\hline SOCIALVOTE & $\begin{array}{l}0.026^{\star *} \\
(0.011)\end{array}$ & $\begin{array}{l}0.026^{\star *} \\
(0.013)\end{array}$ & $\begin{array}{l}0.111^{\star *} \\
(0.044)\end{array}$ & $\begin{array}{l}0.100^{\star *} \\
(0.047)\end{array}$ & $\begin{array}{l}0.033^{\star * \star} \\
(0.013)\end{array}$ & $\begin{array}{l}0.035^{\star *} \\
(0.015)\end{array}$ & $\begin{array}{c}0.087^{\star} \\
(0.048)\end{array}$ & $\begin{array}{c}0.088^{*} \\
(0.053)\end{array}$ \\
\hline SECOND ${ }^{\star S O C . V O T E}$ & & & $\begin{array}{l}-0.095^{\star *} \\
(0.039)\end{array}$ & $\begin{array}{l}-0.093^{\star *} \\
(0.043)\end{array}$ & & & $\begin{array}{l}-0.072 \\
(0.045)\end{array}$ & $\begin{array}{l}-0.079 \\
(0.049)\end{array}$ \\
\hline RIGHT MARGIN*SOC.VOTE & & $\begin{array}{l}-0.507 \\
(0.469)\end{array}$ & $\begin{array}{c}1.149 \\
(0.822)\end{array}$ & $\begin{array}{c}1.197 \\
(0.862)\end{array}$ & & $\begin{array}{l}-0.965 \\
(0.616)\end{array}$ & $\begin{array}{c}0.475 \\
(1.001)\end{array}$ & $\begin{array}{c}0.724 \\
(1.048)\end{array}$ \\
\hline RIGHT MARGIN & & $\begin{array}{c}0.008 \\
(0.005)\end{array}$ & $\begin{array}{c}0.005 \\
(0.006)\end{array}$ & $\begin{array}{c}0.001 \\
(0.006)\end{array}$ & & $\begin{array}{l}-0.001 \\
(0.008)\end{array}$ & $\begin{array}{l}-0.004 \\
(0.008)\end{array}$ & $\begin{array}{l}-0.008 \\
(0.009)\end{array}$ \\
\hline SECOND & & $\begin{array}{l}0.025^{\star *} \\
(0.012)\end{array}$ & $\begin{array}{c}0.024^{\star} \\
(0.013)\end{array}$ & $\begin{array}{c}0.027^{\star} \\
(0.015)\end{array}$ & & $\begin{array}{c}0.021 \\
(0.013)\end{array}$ & $\begin{array}{c}0.020 \\
(0.013)\end{array}$ & $\begin{array}{c}0.021 \\
(0.016)\end{array}$ \\
\hline \multicolumn{9}{|l|}{ Economic } \\
\hline SKILL & $\begin{array}{l}-3.719 \\
(3.244)\end{array}$ & $\begin{array}{l}-2.773 \\
(3.596)\end{array}$ & $\begin{array}{l}-2.487 \\
(3.680)\end{array}$ & $\begin{array}{l}-3.803 \\
(4.328)\end{array}$ & $\begin{array}{l}-2.965 \\
(3.780)\end{array}$ & $\begin{array}{l}-2.774 \\
(4.338)\end{array}$ & $\begin{array}{l}-2.351 \\
(4.403)\end{array}$ & $\begin{array}{l}-2.643 \\
(5.040)\end{array}$ \\
\hline \multicolumn{9}{|l|}{ Control } \\
\hline CATHOLICS & & $\begin{array}{l}-0.003 \\
(0.009)\end{array}$ & $\begin{array}{c}0.015 \\
(0.015)\end{array}$ & $\begin{array}{c}0.021 \\
(0.016)\end{array}$ & & $\begin{array}{l}-0.004 \\
(0.010)\end{array}$ & $\begin{array}{c}0.006 \\
(0.017)\end{array}$ & $\begin{array}{c}0.016 \\
(0.018)\end{array}$ \\
\hline NON AGRICULTURAL & & & $\begin{array}{l}-0.001 \\
(0.001)\end{array}$ & $\begin{array}{l}-0.001^{\star} \\
(0.001)\end{array}$ & & & $\begin{array}{l}-0.000 \\
(0.001)\end{array}$ & $\begin{array}{l}-0.001 \\
(0.001)\end{array}$ \\
\hline CONSTANT & $\begin{array}{c}1.769 \\
(1.954)\end{array}$ & $\begin{array}{l}-0.079 \\
(2.348)\end{array}$ & $\begin{array}{l}-1.367 \\
(2.523)\end{array}$ & $\begin{array}{c}0.983 \\
(2.943)\end{array}$ & $\begin{array}{c}1.001 \\
(2.299)\end{array}$ & $\begin{array}{c}0.306 \\
(2.920)\end{array}$ & $\begin{array}{l}-0.609 \\
(3.026)\end{array}$ & $\begin{array}{c}0.978 \\
(3.366)\end{array}$ \\
\hline $\ln \left(\sigma_{j}^{2}\right)$ & & & & & $\begin{array}{c}0.007 \\
(0.856)\end{array}$ & $\begin{array}{c}0.089 \\
(0.851)\end{array}$ & $\begin{array}{l}-0.070 \\
(0.870)\end{array}$ & $\begin{array}{l}-0.169 \\
(0.930)\end{array}$ \\
\hline Regional fixed effects & $x$ & $\times$ & $x$ & $\sqrt{ }$ & $\times$ & $\times$ & $\times$ & $\sqrt{ }$ \\
\hline Corretly predicted cases & $95.07 \%$ & $94.72 \%$ & $94.72 \%$ & $96.48 \%$ & $95.07 \%$ & $95.07 \%$ & $95.07 \%$ & $96.13 \%$ \\
\hline$N$ & 284 & 284 & 284 & 284 & 284 & 284 & 284 & 284 \\
\hline Bayesian information criterion & 143.706 & 157.356 & 162.232 & 176.313 & 128.995 & 146.127 & 153.951 & 172.358 \\
\hline
\end{tabular}

Note: Standard errors in parentheses; baseline 55.28\%. ${ }^{\star} p<0.10 ;{ }^{* *} p<0.05 ;{ }^{\star * *} p<0.01$. 
by each party is higher than its share of votes. Thus, a positive number reflects a party that gains from the existing electoral arrangement. Negative numbers indicate parties whose fortunes might improve under proportional representation (see Table 1). We use three variables to test for the effects of the district-specific uncertainties postulated by the first Rokkanian hypothesis on the decision of legislators to support proportional representation: a measure of the strength of the Social Democratic party in a district (SOCIALVOTE), a measure of the decisive electoral round which takes the value of 1 if the politician is elected during the second round (SECOND) and a measure of the closeness of the race among nonsocialist parties in the first round (RIGHT MARGIN). ${ }^{10}$

Three additional explanatory variables model differences in economic and social conditions across districts. We use our skill measure (SKILL) to account for the consequences of different "investments in co-specific assets," the critical explanatory variable proposed by Cusack, Iversen, and Soskice (2007). Our measure of differences in economic development is a variable that captures the share of the labor force that is not employed in agriculture (NON AGRICULTURE). We also measure the share of Catholics (CATHOLICS) in a district to account for the possible effects of religious heterogeneity. This measure is consistent with cross-national analyses of the effects of religious fragmentation with the probability of adoption of proportional representation (Boix 1999).

We first estimate four different model specifications. In all models the outcome is whether a member of the Reichstag voted yes or no on the proposal to introduce proportional representation. All four models are presented in Table 2. The first specification, Model 1, is a probit model which includes variables relating to the three theoretically interesting concepts; the seat-vote disproportionality, the strength of left parties, and the average skill level in a district. The second specification, Model 2, adds a number of controls for the tightness of the election in a district (RIGHT MARGIN, SECOND) as well as the

\footnotetext{
${ }^{10}$ Capturing the potential for coordination with the measure of RIGHT MARGIN, rather than using effective number of right parties, is also in line with more recent research which finds that alliances are more likely when there is a clear strong party and a clearly weaker one (e.g., Blais and Indridason 2007).
}

controls (CATHOLICS ${ }^{11}$, NON AGRICULTURAL). The third model also includes two interactions, one between SOCIALVOTE and SECOND and one between RIGHT MARGIN and SOCIALVOTE. These interactions reflect the theoretical argument; when politicians are elected in a second round, their district is already competitive. Hence the strength of the left parties or the right margin should add less to their propensity to support Proportional Representation than if they were elected in the first round. Finally, in Model 4, we also include regional fixed effects as an illustration of the robustness of the results.

As hypothesized, we find a negative effect for seat-vote disproportionality across all specifications. The more disadvantageous the seat-vote ratio under majoritarian elections is for a party, the more likely it will be that its members support a change to proportional representation (Rokkan II). An increase in the strength of the left parties in a district increases the likelihood that the politicians will support a change in electoral rules (Rokkan I). Finally, there is no effect for the average skill level in a district on the willingness of the representative to support changes in electoral institutions. A comparison of the estimates from Model 2 (without interactions) and Model 3 (with interactions) shows how the size of the coefficient for SOCIALVOTE more than triples while the interaction (with SECOND) is negative and significant. The explanation for the increase in the size of the coefficient for SOCIALVOTE is that we now allow the model to have two different effects for SOCIALVOTE: one for politicians elected in the first round and one for those politicians elected in the second round. The left threat exerts an effect for politicians which were elected in the first round while those representatives which had to face a run-off are already in competitive districts, and the left threat should affect them less. The change of $\hat{\beta}_{\text {SOCIALVOTE }}$ from Model 2 to Model 3

\footnotetext{
${ }^{11}$ Rokkan's second hypothesis comes in fact in two different specifications. The first of these specifications suggests that one of the motivations for the adoption of proportional representation is the protection of the minorities. The second explanation suggests that the geographic efficiency of votes is the main determinant of the preferences of parties (Calvo 2009). To test for the first hypothesis, we include a measure of the share of Catholics in a district. One expects that politicians from districts with a higher percentage of Catholic voters should support the adoption of proportional representation. We find no support for this hypothesis. Moreover, our analysis suggests that the interpretation of the second Rokkanian hypothesis as one about seat-vote disproportionality is the appropriate one in this case. The Zentrum, the party representing Catholic voters did, in fact, oppose the adoption of proportional representation. Zentrum politicians won from the seat-vote disproportionality of the electoral system and had thus reasons to oppose changes in electoral rules.
} 


\section{Figure 1 Support of Proportional Adoption}

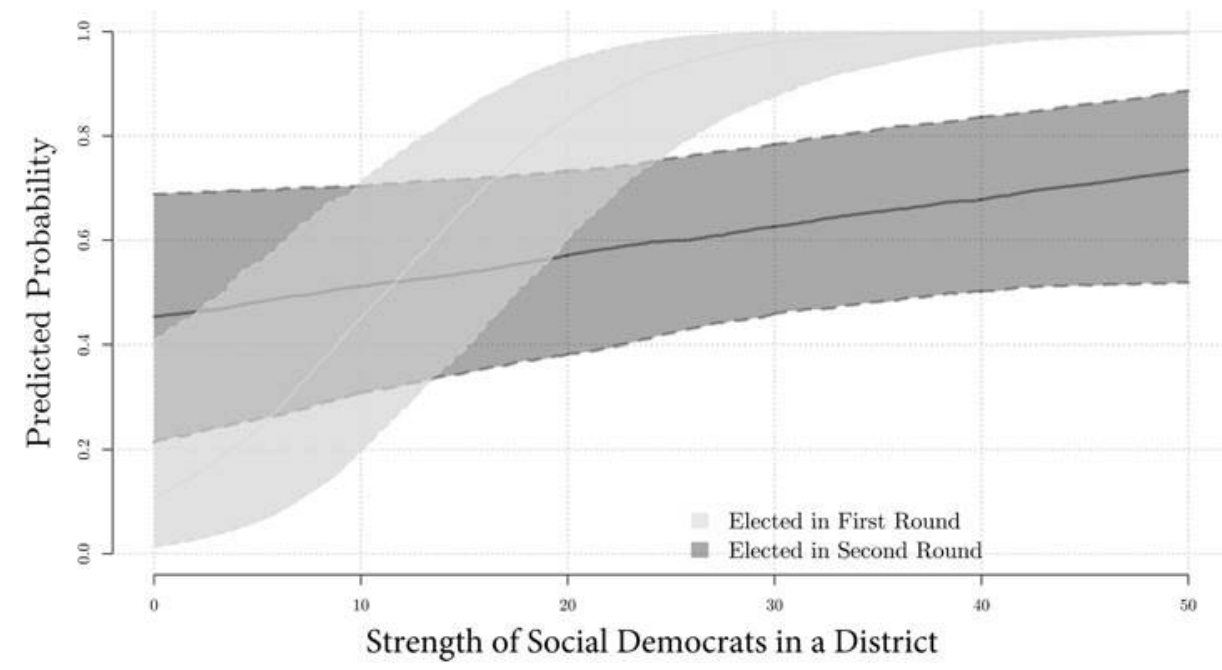

is consistent with the theoretical predictions of the first Rokkanian hypothesis. Finally, adding fixed effects does not change the estimates in any meaningful way with the exception that the interaction between RIGHT MARGIN and SOCIALVOTE achieves statistical significance. ${ }^{12}$

To fully illustrate these effects, we present a figure with predicted probabilities to clarify the interaction effects (see Figure 1). We plot the predicted probabilities for two hypothetical cases where the only difference is that one legislator was elected in the first round and the other was elected in a run-off. Simulation results rest on estimates from Model 3 and the predicted probabilities are displayed with \pm one standard deviation. The marginal effect of the strength of the SPD in a district has a positive and significant effect. In addition, the magnitude of effect is stronger in those districts which did not require a runoff election.

Finally, we turn our attention to the economic predictors. In all specifications, we find that the average skill ratio of a district has no significant influence on the probability of a legislator voting "yes" on the adoption of proportional representation. But we do find an effect for economic modernization (NON AGRICULTURE), but this effect is not robust and disappears in alternative model specifications. The nonfinding for SKILL does not depend on the inclusion of NON AGRICULTURE; all models support the null hypothesis that there is no

\footnotetext{
${ }^{12} \mathrm{~A} \chi^{2}$ test whether SECOND and SECOND ${ }^{\star S O C . V O T E}$ are significant predictors or not yields a test statistic of $\chi_{2}^{2}=13.28$ and a $p$-value of 0.001 based on Model 3 (for Model 4: $\chi_{2}^{2}=10.24$ and a $p$-value of 0.005$)$.
}

relation between the probability of a "yes" vote and the average skill level. ${ }^{13}$

In addition to these results, we perform a number of robustness checks and present all the estimation results in the online appendix. We present the same models but use two alternative measures of skilled labor force-skill level of total work force as well as a measure of skill that is aggregated over regions. The results are presented in Table 1 and Table 3 in the online appendix. Among these alternative models presented in the appendix, we also estimate a model that examines the vote choice of nonsocialist representatives in the Reichstag only and excludes the Social Democratic candidates. The results reinforce our confidence in the explanatory value of the electoral threat of the left on the political support for changes in electoral rules (see Table 7 in the online appendix). Finally, we also reestimate alternative models where we include a measure of population size to control for possible effects of malapportionment (Table 5 in the online appendix). In all specifications the results remain stable; the seat-vote disproportionality has a significant and negative effect on support for proportional representation, the strength of the left vote in a district has a positive and significant effect, and there is no statistical relation between skill levels and voting behavior.

The two Rokkanian arguments do not apply to the same level of analysis. The left threat is a district level variable whereas the seat-vote disproportionality is a party-level variable. To take these different levels fully into account empirically, we reestimate Models 1

\footnotetext{
${ }^{13}$ In an estimation of Model 4 that excludes NON AGRICULTURE, we find $\hat{\beta}_{\text {SKILL }}=-4.5$ and a $p$-value of 0.289 .
} 
through 4 including respecifications that take the hierarchical data structure into account (Gelman and Hill 2007; Steenbergen and Jones 2002). Table 2 presents the estimation results for Models 5 through 8 which are hierarchical probit models, where the first level is the district level and the second level is the partisan level.

Again, the outcome variable in both models is the vote of a single member of parliament. The specification is identical to the models in Table 2 with the exception that we model the seat-vote disproportionality (SEAT VOTE DISPR) as a level two variable and include a random effect which varies over parties. ${ }^{14}$ The substantive effects and statistical significance of the three most important variables that model the three competing explanations about the adoption of proportional representation (seat-vote disproportionality, skill level, and left strength) remain unchanged when compared to previous specifications presented in Table 2.

Moreover, the effects of these variables do not change across all models presented in Table 2. In these specifications, the measure of economic development (NON AGRICULTURAL) no longer reaches statistical significance at conventional levels, when compared to Models 1-4. The coefficients of the interaction between the second round and the Social Democratic vote and the right margin and the Social Democratic vote also do not reach statistical significance. These changes notwithstanding, we find that the tests of the relevant theoretical hypotheses remain unchanged. The skill level in a district has no effect on the probability that a legislator in the Reichstag will support a change of the electoral system. By contrast, political variables exercise a considerable effect. Increases in seat-vote disproportionality and the strength of the left-wing candidate competing in a district increase the probability of support for proportional representation.

Figure 2 presents predicted probabilities for support of changes in the electoral system. The light grey curve presents changes in the probability of support for proportional representation of a legislator representing the National Liberal party for different levels of electoral strength of the Social Democratic challenger (left threat). The dark grey curve represents similar probabilities for members of the Zentrum.

National Liberal legislators are more likely to support a change in the electoral system even if there is no left threat at all. This can be explained by the

\footnotetext{
${ }^{14}$ Subscript $i$ describes legislators and subscript $j$ pertains to parties: $\operatorname{Pr}\left(\operatorname{Vote}_{i j}=1\right)=\boldsymbol{\Phi}\left(\beta_{0 j}+\boldsymbol{\beta} \boldsymbol{X}_{i j}\right) ; \beta_{0 j}=\alpha_{0}+\alpha_{1} \cdot S V D_{j}+u_{j}$; and $u_{j} \sim N\left(0, \sigma_{u}\right)$. The first equation describes the level 1 model where $\boldsymbol{X}_{i j}$ denotes the matrix of the explanatory variables and $\boldsymbol{\beta}$ is a vector of regression coefficients with the same number of elements as there are explanatory variables.
}

unfavorable allocation of seats to votes experienced by this party during the 1912 election. By contrast, a hypothetical legislator representing the Zentrum found the existing electoral rules more attractive. The Zentrum, a party with strong regional strongholds in Bavaria, Baden, and the Ruhr benefited from allocation of votes to seats under the existing electoral rules throughout the Imperial Period. During the 1912 elections, the Zentrum ended up receiving a surplus in the allocation of seats of (+6.1\%-points). Despite these differences across parties, the plot reveals that an increase in the left-wing threat increased the probability of support of changes in electoral rules for both the National Liberal and the Zentrum representatives.

One might object to the operationalization of skill level as a district variable and claim that the skill mechanism rather works through the party. In that logic, the individual representative might be responsive even if his own district is not endowed with a high skill level but rather most other members of his party have districts with above-average skill levels. We also provide estimation results for that operationalization where we first aggregate average skill level for each party separately to the party level (average of skill level for all districts held by a party) and add this variable as a party-level variable to the hierarchical model. The results are substantively identical to the models presented in Table 2 . There is a negative and significant effect for seat-vote disproportionality, a positive and significant effect for the strength of the left in a district, and no relationship between the skill level and the propensity to support proportional representation (see Table 6 in the online appendix). ${ }^{15}$

\section{Party Defection and Left Threat}

The two political variables that impinge upon the political decisions of legislators - the left threat in individual districts versus party interests-reinforce each other on some occasions, but can, on other occasions, pull in different directions. In this section, we examine those cases where legislators defected from their party position and voted against the party's interest. Can such defections be explained by individual-district motivations?

To illustrate how district-level and partisan consideration can come into conflict with each other, consider

\footnotetext{
${ }^{15} \mathrm{We}$ also estimated a model in which we let the coefficients vary over parties and uncover the same estimates with respect to significance level and direction of effect.
} 


\section{FIGURE 2 Seat-Vote Disproportionality}

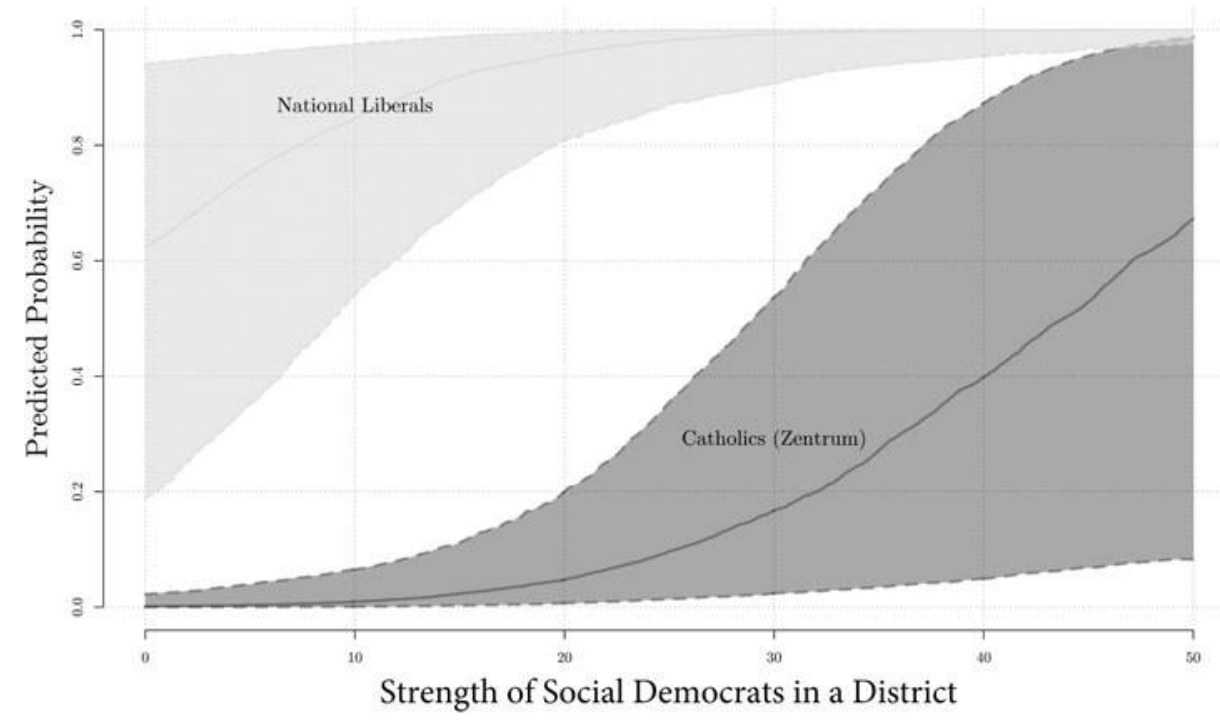

the case of politicians from the two parties opposing the adoption of proportional representations-Zentrum and Conservatives-who face a strong Social Democratic threat in their district. In this case, partisan considerations pull the politician towards support for existing electoral rules, while district-level calculations pull in the direction of changes in electoral systems. The defection of these politicians from the position advocated by their party can be explained by district-level competition. This is the case, for example, of Eugen Schatz-a Zentrum poli- tician from Saargemünd-Forbach who supported the adoption of proportional representation. Schatz had won his seat with a narrow margin against a Social Democratic opponent. Albert Thumann, a politician from Gebweiler and another Zentrum politician who defected from the position of his party-had also clinched victory narrowly (with a majority of $55 \%$ of the votes) against a Social Democratic challenger.

In Table 3, we present an array of five different models explaining defection from the party line for the Catholics (Zentrum) and the Conservatives. As

\section{Table 3 Logit Models on Party Defection}

\begin{tabular}{|c|c|c|c|c|c|}
\hline & Model 9 & Model 10 & Model 11 & Model 12 & Model 13 \\
\hline SOCIALVOTE & $\begin{array}{l}0.092^{\star \star} \\
(0.040)\end{array}$ & & $\begin{array}{l}0.118^{\star *} \\
(0.052)\end{array}$ & & $\begin{array}{c}0.110^{\text {} \star} \\
(0.052)\end{array}$ \\
\hline SKILL & & $\begin{array}{l}-18.703 \\
(12.452)\end{array}$ & & $\begin{array}{l}-15.080 \\
(13.562)\end{array}$ & $\begin{array}{l}-12.926 \\
(15.403)\end{array}$ \\
\hline RIGHT MARGIN & & & $\begin{array}{c}0.006 \\
(0.026)\end{array}$ & $\begin{array}{l}-0.018 \\
(0.027)\end{array}$ & $\begin{array}{c}0.012 \\
(0.028)\end{array}$ \\
\hline NON AGRICULTURAL & & & $\begin{array}{c}0.002 \\
(0.032)\end{array}$ & $\begin{array}{c}0.018 \\
(0.030)\end{array}$ & $\begin{array}{l}-0.009 \\
(0.036)\end{array}$ \\
\hline CATHOLICS & & & $\begin{array}{l}-0.058 \\
(0.043)\end{array}$ & $\begin{array}{l}-0.025 \\
(0.044)\end{array}$ & $\begin{array}{l}-0.067 \\
(0.045)\end{array}$ \\
\hline SECOND & & & $\begin{array}{l}-3.116 \\
(1.976)\end{array}$ & $\begin{array}{l}-2.121 \\
(1.769)\end{array}$ & $\begin{array}{l}-2.747 \\
(1.980)\end{array}$ \\
\hline CONSERVATIVE & $\begin{array}{l}-2.911^{\star} \\
(1.599)\end{array}$ & $\begin{array}{l}-1.840 \\
(1.482)\end{array}$ & $\begin{array}{l}-5.336 \\
(3.549)\end{array}$ & $\begin{array}{l}-2.759 \\
(3.454)\end{array}$ & $\begin{array}{l}-5.983 \\
(3.922)\end{array}$ \\
\hline Constant & $\begin{array}{l}-3.754^{\star * \star} \\
(0.883)\end{array}$ & $\begin{array}{c}8.769 \\
(7.251)\end{array}$ & $\begin{array}{c}0.554 \\
(3.522)\end{array}$ & $\begin{array}{c}8.811 \\
(10.099)\end{array}$ & $\begin{array}{c}9.473 \\
(11.487)\end{array}$ \\
\hline$N$ & 108 & 108 & 108 & 108 & 108 \\
\hline Bayesian information criterion & 43.789 & 57.927 & 37.577 & 52.378 & 46.577 \\
\hline
\end{tabular}

Note: Standard errors in parentheses; - Logit model with penalized maximum-likelihood function, "firthlogit" Firth (1993). ${ }^{\star} p<0.10 ;{ }^{* *} p<0.05 ;{ }^{* *} p<0.01$. 
hypothesized, the strength of the vote of the Social Democratic candidate in a district (SOCIALVOTE) can explain party defection. All specifications include the alternative explanatory variable proposed by Cusack, Iversen, and Soskice $(2007,2010)$ which is the district skill level (SKILL) as well as the control variables from Models 1-8. We also add a dichotomous indicator for Conservatives to allow for party differences. In the online appendix, we present the same models estimated only on members of Zentrum as well as with an alternative underlying model (see Table 8, Table 9, and Table 10). Since the variable (SECOND) causes perfect separation (it perfectly predicts the outcome), we use a logit model based on a penalized maximum-likelihood function to overcome this problem (Firth 1993) which is similar to a Bayesian estimation of the model.

Regardless which model specification, all results in Models 9 through 13 (and the alternative specifications in the appendix) support the first Rokkanian hypothesis that legislators facing a strong raising left support proportional representation. Those members of Zentrum and the Conservatives who defected from the party line were facing considerably stronger left candidates in their districts.

Those members of Zentrum who voted against their party line faced significantly stronger left contenders in their districts. This illustrates the strength of Rokkan's two hypotheses when they are allowed to jointly explain the same observations on the party level as well as the individual district level. We have now not only established that the two Rokkanian hypotheses can explain the overall vote outcome and the adoption of $\mathrm{PR}$, but we also illustrated that Rokkan I (Social Democratic vote share as threat) explains party defection among those parties that share an electoral advantage from using SMD and thereby shows that these two explanations are not two different roads leading to PR but arguments which apply simultaneously at different levels of analysis within the same case.

\section{Conclusion}

We have started this article by noting a paradoxical situation in the recent literature examining the origin of proportional representation. The flurry of articles in prominent publications notwithstanding, one was left wondering which of explanations does a better job in accounting for the choice of electoral rules in European countries during the first decades of the twentieth century. The current debate has been framed as a horse-race between the first Rokkanian hypothesis and the economic arguments formulated by Cusack, Iversen, and Soskice (2007), to the neglect of alternative explanations (which are also Rokkanian in origin) that attribute an important role to partisan calculations (an exception is Calvo 2009).

In this article, we have argued that political demand for the adoption of proportional representation can be attributed to factors that operate at two distinct levels. One set of considerations operate at the level of the party. Disproportionalities in the translation of votes to seats and perceptions of possible gains in the allocation of seats under the new electoral rules affect partisan considerations about the desirability of changes in electoral rules. These factors explain variation in positions among parties on the right and the position of Social Democratic parties on the issue of electoral reforms. A second set of factors that impinge upon the decisions of politicians operate at the level of the electoral district. Here vulnerability to electoral competition from left-wing candidates can explain some additional variation in political support for changes in electoral rules among candidates on the political right and the willingness of the latter to support or deviate from the position advocated by their parties. While these political hypotheses go back to the work of Rokkan, we reformulate and clarify the Rokkanian conjectures. We argue that it is more useful to think about the two political hypotheses about the adoption of proportional representation as identifying complementary constraints on politicians, rather than as "separate paths" chosen by different countries. Empirically, we demonstrate that both logics are at work within the same case and that they identify different sources of demand for changes in electoral rules.

Our article also proposes a new empirical strategy to examine the question of changes in electoral rules that departs from a reliance on a cross-national analysis. We propose to change the unit of analysis from countries to individual legislators and bring back individual politicians to the center of the analysis. This empirical strategy has several advantages over cross-national research. The first is that it allows us to test existing explanations at the salient level, the level of the district, rather than the level of the country. Secondly, it allows to consider all the relevant political and economic hypotheses and not just a subset of the latter. Finally, we improve upon existing studies by developing more precise measures of the salient political and economic variables. 
We find that political support for the adoption of proportional representation was affected by partisan considerations about the disproportionality in the translation of seats to votes and by political conditions in a district. We do not find that legislative support can be explained by skill levels regardless of the many alternative specifications we employ. Our empirical analysis disconfirms the economic hypothesis about the adoption of proportional representation. But given that Germany is a "hard case" for Rokkanian explanations, we believe that our findings weaken significantly our confidence in the comparative explanatory power of economic hypotheses for the adoption of proportional representation. Our findings also qualify the Rokkanian hypothesis about the importance of the Social Democratic threat as a determinant of the adoption of proportional representation in Germany. We show that political choices made by German legislators over the adoption of proportional representation can be explained by a combination of partisan dissatisfaction and district-level vulnerabilities. Contra Rokkan, we show that choices over electoral rules are affected by a combination of partisan and electoral considerations and not by district-level vulnerabilities to the Social Democratic threat only.

\section{Acknowledgments}

We thank the editors and three anonymous reviewers as well as Kate Baldwin, Pablo Beramendi, Matthew Carnes, Holger Döring, Miriam Golden, Shigeo Hirano, John Huber, Kimuli Kasara, Jeff Lax, Yotam Margalit, Kevin Mazur, Pierce O’Reilly, Susan Stokes, Pavithra Suryanarayan, Didac Queralt, Fabio Wasserfallen, Steven Wilkinson, and seminar participants at Princeton University, Lund University, and Sciences Po Paris for helpful comments and ideas.

\section{References}

Ahmed, Amel. 2012. Democracy and the Politics of Electoral System Choice: Engineering Electoral Dominance. Cambridge: Cambridge University Press.

Anderson, Margaret Lavinia. 2000. Practicing Democracy: Elections and Political Culture in Imperial Germany. Princeton, NJ: Princeton University Press.

Andrews, Josephine T., and Robert W. Jackman. 2005. "Strategic Fools: Electoral Rule Choice under Extreme Uncertainty." Electoral Studies 24 (1): 65-84.

Bade, Klaus. 1980. Massenwanderung und Arbeitsmarkt im deutschen Nordosten 1880-1914. Archiv für Sozialgeschichte.

Benoit, Kenneth. 2004. "Models of Electoral System Change." Electoral Studies 23 (3): 363-89.
Bertram, Juergen. 1964. Die Wahlen zum deutschen Reichstag vom Jahre 1912: Parteien und Verbände in der Innenpolitik des Wilhelminischen Reiches. Düsseldort, Ger.: Droste.

Blais, André, Agnieszka Dobrzynska, and Indridi Indridason. 2005. "To Adopt or Not to Adopt Proportional Representation: The Politics of Institutional Choice." British Journal of Political Science 35 (1): 182-90.

Blais, André, and Indridi H. Indridason. 2007. "Making Candidates Count: The Logic of Electoral Alliances in Two-Round Legislative Elections." Iournal of Politics 69 (1): 193-205.

Boix, Carles. 1999. "Setting the Rules of the Game: The Choice of Electoral Systems in Advanced Democracies." The American Political Science Review 93 (3): 609-24.

Boix, Carles. 2010. "Electoral Markets, Party Strategies, and Proportional Representation." American Political Science Review 104 (2): 404-13.

Brandenburg, Erich. 1917. 50 Jahre Nationalliberale Partei: 18671917. LeiptiGer.: Schriftenvertriebsstelle der Nationalliberalen Partei Deutschlands, Kalkoff.

Braunias, Karl. 1932. Das parlamentarische Wahlrecht: Ein Handbuch über die Bildung der gesetzgebenden Körperschaften in Europa. Vol. 2. Berlin: W. de Gruyter.

Bundesarchiv, Berlin Lichterfeld. 1912. Betrachtungen über die Einteilung der Reichstagswahlkreise. R 1501/309-363.

Calvo, Ernesto. 2009. "The Competitive Road to Proportional Representation. Partisan Biases and Electoral Regime Change under Increasing Party Competition." World Politics 61 (2): 254-95.

Caramani, Daniele. 2004. The nationalization of politics: The formation of national electorates and party systems in Western Europe. Cambridge University Press.

Colomer, Josep M. 2005. "It's Parties That Choose Electoral Systems (or, Duverger's Laws Upside Down)." Political Studies 53 (1): 1-21.

Cox, Gary W. 1997. Making Votes Count: Strategic Coordination in the World's Electoral Systems. Cambridge: Cambridge University Press.

Cusack, Thomas, Torben Iversen, and David Soskice. 2007. "Economic Interests and the Origins of Electoral Systems." The American Political Science Review 101 (3): 373-91.

Cusack, Thomas, Torben Iversen, and David Soskice. 2010. "Coevolution of Capitalism and Political Representation: The Choice of Electoral Systems." American Political Science Review 104 (2): 393-403.

Duverger, Maurice. 1954. Political Parties: Their Organization and Activity in the Modern State. New York: John Wiley.

Fairbairn, Brett. 1990. "Authority vs. Democracy: Prussian Officials in the German Elections of 1898 and 1903." Historical Lournal 33 (4): 811-38.

Firth, David. 1993. "Bias Reduction of Maximum Likelihood Estimates." Biometrika 80 (1): 27-38.

Fremdling, Rainer, and Richard Tilly. 1979. Industrialisierung und Raum. Studien zur regionalen Differenzierung im Deutschland des 19.Jahrhunderts.Stuttgart, Ger.: Klett-Cotta.

Fricke, Dieter. 1961. "Der deutsche Imperialismus und die Reichstagswahlen von 1907.” Zeitschrift für Geschichstwissenschaft 9 (3): 538-76.

Gagel, Walter. 1958. Die Wahlrechtsfrage in der Geschichte der deutschen liberalen Parteien: 1848-1918. Vol. 12. Düsseldort, Ger.: Droste Verlag. 
Gelman, Andrew, and Jennifer Hill. 2007. Data Analysis Using Regression and Multilevel/Hierarchical Models. Cambridge: Cambridge University Press.

George, Alexander L., and Andrew Bennett. 2005. Case Studies and Theory Development in the Social Sciences. Cambridge, MA: MIT Press.

Hatschek, Julius. 1920. Kommentar zum Wahlgesetz und zur Wahlordnung im deutschen Kaiserreich. Berlin, Ger.: Walter de Gruyter.

Hohls, Rüdiger, and Hartmut Kaelble. 1989. Die regionale Erwerbsstruktur im deutschen Reich und in der Bundesrepublik Deutschland. St. Katharinen, Ger.: Scripta Mercaturae Verlag.

Kaiserliches-Statistisches-Amt. 1899. Die berufliche und soziale Gliederung des deutschen Volkes nach der Berufszählung vom 14. Juni 1895. Berlin: Verlag des Königlich Preussischen Statistischen Bureaus.

Kaiserliches-Statistisches-Amt. 1913. Die Reichstagswahlen von 1912. In Statistik des Deutschen Reiches, Band 250, Zweites Heft. Berlin: Von Puttkammer und Mühlbrecht.

Kreuzer, Marcus. 2010. "Historical Knowledge and Quantitative Analysis: The Case of the Origins of Proportional Representation." American Political Science Review 104 (2): 369-92.

Kühne, Thomas. 1994. Landtagswahlen zwischen korporativer Tradition und politischem Massenmarkt. In Dreiklassenwahlrecht und Wahlkultur in Preussen 1867-1914. Düsseldorf, Ger.: Droste.

Kuo, Alexander. 2010. “The Political Origin of Firms' Strategies." $\mathrm{PhD}$ thesis, Stanford University.

Norris, Pippa. 1997. "Choosing Electoral Systems: Proportional, Majoritarian and Mixed Systems." International Political Science Review 18 (3): 297-312.

Penadés, Alberto. 2008. "The Institutional Preferences or Early Socialist Parties: Choosing Rules for Government." In Cambridge: Cambridge University Press, 202-46. Controlling Governments - Voters, Institutions, and Accountability, eds. José María Maravall.
Penadés, Alberto. 2011. "Electoral Reform in Early Democracies: The Right Wing." Presented at the Conference on Historical Political and Economic Development in Western Europe: Recent Advances in Comparative Politics, Madrid.

Reibel, Carl-Wilhelm. 2007. Handbuch der Reichstagswahlen 1890- 1918. Bündnisse, Ergebnisse, Kandidaten. Düsseldor, Ger.: Droste.

Rogowski, Ronald. 1987. "Trade and the Variety of Democratic Institutions.” International Organization 41 (02): 203-23.

Rokkan, Stein. 1970. Citizens Elections Parties. New York: David McKay.

Schmädeke, Jurgen. 1995. Wählerbewegung im Wilhelminischen Deutschland: Die Reichstagswahlen von 1890 bis 1912. Berlin, Ger.: Akademie Verlag.

Simon, Klaus. 1969. Die württembergischen Demokraten: Ihre Stellung und Arbeit im Parteien- und Verfassungssystem in Württemberg und im Deutschen Reich 1890-1920. Vol. 52. Stuttgart, Ger.: Kohlhammer.

Steenbergen, Marco R., and Bradford S. Jones. 2002. "Modeling Multilevel Data Structures." American Journal of Political Science 46: 218-37.

Thelen, Kathleen. 2004. How Institutions Evolve: The Political Economy of Skills in Germany, Britain, the United States and Japan. New York: Cambridge University Press.

Lucas Leemann is a Ph.D. candidate in the Department of Political Science, Columbia University, New York City, NY.

Isabela Mares is a Professor in the Department of Political Science, Columbia University, New York City, NY. 